\title{
Reference ranges for cardiac dimensions and blood flow velocity in preterm infants
}

\author{
R Skelton, A B Gill, J M Parsons
}

\begin{abstract}
Aim-To establish reference ranges for cardiac dimensions and Doppler measurements in preterm infants.

Methods-79 infants of less than 34 weeks' gestation were examined by echocardiography on days 0,7 , and 28 after birth, to produce a set of reference ranges and to examine changes in these indices over the first month of life. The following dimensions were measured: interventricular septum, left ventricular posterior wall, left interventricular diameter at end systole and diastole, left atrium, and aortic root; Doppler measurements were made of maximum blood flow velocity (Vmax) through the pulmonary, aortic, mitral, and tricuspid valves.

Results-Reference ranges are given. Cardiac dimensions correlated well with gestation and birth weight but Vmax did not. There was a significant increase in measurements over time. The "normal" preterm infant also appeared to often have asymmetrical septal hypertrophy. Antenatal dexamethasone administration did not appear to affect the measurements. Conclusions-There is a close correlation with both gestation and birth weight for all physical measurements. Echocardiograms in preterm babies clearly differ from those in older children and adults. (Heart 1998;80:281-285)
\end{abstract}

\section{Table 1 Characteristics of the babies}

\begin{tabular}{ll}
\hline Number & 79 \\
Gestation (mean (range), weeks) & $29(23$ to 33$)$ \\
Birth weight (mean (range), g) & $1242(580$ to 2380$)$ \\
Male:female (n) & $48: 31$ \\
Patent arterial duct & $61 \%$ \\
Ventilation: CPAP & $10 \%$ \\
Ventilation: IMV & $57 \%$ \\
Inotropes & $22 \%$ \\
Antenatal dexamethasone (2+ doses) & $57 \%$ \\
\hline CPAP, continuous positive airway pressure; IMV, intermittent \\
mechanical ventilation.
\end{tabular}

Table 2 Cardiac dimensions $(\mathrm{mm})$ at $0-3$ days of age by gestation

\begin{tabular}{llllllll}
\hline $\begin{array}{l}\text { Gestation } \\
\text { (weeks) }\end{array}$ & $n$ & IVS & LIDDd & LVPWd & LIDDs & LA & AO \\
\hline 23 to 25 & 9 & 2.1 & 10.1 & 2.0 & 7.2 & 7.1 & 5.4 \\
& & 1.4 to 2.8 & 7.9 to 12.3 & 1.5 to 2.5 & 4.8 to 9.6 & 2.6 to 11.6 & 4.2 to 6.6 \\
26 to 28 & 27 & 2.5 & 11.4 & 2.3 & 8.0 & 7.5 & 6.5 \\
& & 1.5 to 3.5 & 7.2 to 15.6 & 1.3 to 3.3 & 5.2 to 10.8 & 4.7 to 11.2 & 4.7 to 8.2 \\
29 to 31 & 22 & 2.6 & 13.1 & 2.5 & 9.1 & 7.5 & 7.1 \\
& & 1.5 to 3.7 & 9.7 to 16.5 & 1.9 to 3.1 & 5.8 to 12.4 & 4.9 to 10.1 & 5.4 to 8.8 \\
32 to 33 & 21 & 2.9 & 13.8 & 2.7 & 9.5 & 8.1 & 7.9 \\
& & 1.7 to 4.1 & 10.2 to 17.4 & 2.1 to 3.3 & 6.1 to 12.9 & 4.5 to 11.7 & 5.7 to 10.1 \\
\hline
\end{tabular}

Values are mean and $\pm 2 S D$.

$\mathrm{AO}$, aortic root; IVS, interventricular septum; LA, left atrium; LIDDd (s), left interventricular diameter at end diastole (end systole); LVPWd, left ventricular posterior wall thickness at end diastole.
Keywords: cardiac dimensions; blood flow velocity; preterm infant

Echocardiography has been available for the evaluation of cardiac abnormality and function for over 20 years. Good reference ranges of cardiac measurements were soon produced for adults, children, and term infants. ${ }^{12}$ However, these have not been updated in line with improvements in scanning, or extended to include the large number of extremely small, premature infants surviving with modern intensive care. Normal values of blood flow velocities for such infants are even less well studied. While fully skilled cardiologists are required for the full assessment and diagnosis of cardiac abnormality, neonatologists are now using echocardiography to assess and investigate cardiac function, ductal patency, and changes in premature infants. There is therefore a need for new references ranges of values for the neonatal unit.

Our main aim was to establish a reference range of measurements of cardiac size and blood flow velocities for the population of premature infants cared for in our neonatal unit. We followed these measurements over the first week and month of life. We also looked at the effect on the measurements of a number of variables.

We had also noticed, while examining preterm babies, that they often have features considered abnormal on adult echocardiography. For example, on tracings of the blood flow velocity across the mitral and tricuspid valves the usual ratio of $a$ and e waves appeared to be inverted. Also the ratio of the interventricular septum to left ventricular posterior wall appeared to be increased. We therefore also looked at these two aspects of the echocardiographic examination in relation to the accepted adult features.

\section{Methods}

PATIENTS

We studied all preterm babies under 34 weeks' gestation admitted to the Peter Congden neonatal unit at Leeds General Infirmary over a seven month period (May to November 1995). The following babies were excluded from the reference ranges: those with congenital heart disease (other than a patent arterial duct); babies of mothers with diabetes (gestational and non-gestational), as they are known to have increased septal thickness; babies receiving dexamethasone for chronic lung disease, as this produces a hypertrophy of the left ventricle ${ }^{3}$; babies with major congenital abnormalities; and growth retarded babies (IUGR, birth weight less than 10th centile). The study was prospective and received local ethics committee approval. 
Table 3 Cardiac dimensions $(\mathrm{mm})$ at $0-3$ days of age in relation to birth weight

\begin{tabular}{llllllll}
\hline $\begin{array}{l}\text { Birth weight } \\
(g)\end{array}$ & $n$ & IVS & LIDDd & LVPW & LIDDs & LA & AO \\
\hline 500 to 1000 & 25 & 2.3 & 10.7 & 2.1 & 7.5 & 6.7 & 6.0 \\
& & 1.3 to 3.3 & 7.9 to 13.5 & 1.5 to 2.7 & 4.7 to 10.3 & 3.1 to 10.3 & 4.4 to 7.6 \\
1000 to 1499 & 35 & 2.6 & 12.4 & 2.5 & 8.6 & 7.7 & 7.3 \\
& & 1.8 to 3.4 & 9.4 to 15.4 & 1.8 to 3.2 & 5.8 to 11.4 & 4.9 to 10.5 & 5.3 to 9.3 \\
1500 to 1999 & 16 & 2.8 & 14.4 & 2.6 & 9.8 & 8.4 & 7.4 \\
2000 to 2499 & 3 & 3.6 & 14.8 & 3.1 & 11.2 & 9.4 & 8.1 \\
\hline
\end{tabular}

Values are mean and $\pm 2 \mathrm{SD}$.

AO, aortic root; IVS, interventricular septum; LA, left atrium; LIDDd (s), left interventricular diameter at end diastole (end systole); LVPWd, left ventricular posterior wall thickness at end diastole.

Table 4 Cardiac dimensions ( $\mathrm{mm}$ ) at 7 days of age by gestation

\begin{tabular}{llllllll}
\hline $\begin{array}{l}\text { Gestation } \\
\text { (weeks) }\end{array}$ & $n$ & IVS & LIDDd & LVPW & LIDDs & LA & AO \\
\hline 23 to 25 & 7 & 2.8 & 10.7 & 2.6 & 7.3 & 6.9 & 6.4 \\
& & 2.0 to 3.8 & 7.3 to 14.1 & 1.8 to 3.4 & 3.1 to 11.5 & 2.1 to 11.7 & 4.8 to 8.0 \\
26 to 28 & 20 & 2.8 & 11.9 & 2.7 & 7.9 & 8.4 & 6.8 \\
& & 1.4 to 4.2 & 7.5 to 16.3 & 1.7 to 3.7 & 4.9 to 11.9 & 5.0 to 11.8 & 5.2 to 8.4 \\
29 to 31 & 15 & 2.7 & 12.9 & 2.8 & 8.8 & 7.6 & 7.2 \\
& & 2.1 to 3.3 & 8.7 to 17.1 & 2.1 to 3.5 & 6.7 to 10.9 & 5.4 to 9.8 & 5.6 to 9.8 \\
32 to 33 & 14 & 3.2 & 14.3 & 2.6 & 10.3 & 8.7 & 8.1 \\
& & 4.2 to 5.2 & 11.1 to 17.5 & 1.6 to 3.6 & 7.3 to 13.3 & 5.0 to 11.4 & 5.7 to 10.5 \\
\hline
\end{tabular}

Values are mean and $\pm 2 S D$.

$\mathrm{AO}$, aortic root; IVS, interventricular septum; LA, left atrium; LIDDd (s), left interventricular diameter at end diastole (end systole); LVPWd, left ventricular posterior wall thickness at end diastole.

Table 5 Cardiac dimensions $(\mathrm{mm})$ at 7 days of age in relation to birth weight

\begin{tabular}{llllllll}
\hline $\begin{array}{l}\text { Birth weight } \\
(\mathrm{g})\end{array}$ & $n$ & IVS & LIDDd & LVPW & LIDDs & LA & AO \\
\hline 500 to 1000 & 18 & 2.7 & 11.4 & 2.6 & 7.8 & 7.9 & 6.5 \\
& & 1.9 to 3.5 & 7.2 to 15.6 & 2.0 to 3.2 & 4.0 to 11.6 & 3.5 to 12.3 & 5.1 to 7.9 \\
1000 to 1499 & 22 & 2.8 & 12.3 & 2.7 & 8.5 & 7.8 & 7.2 \\
& & 1.4 to 4.2 & 8.9 to 15.7 & 1.7 to 3.7 & 6.5 to 10.5 & 5.2 to 10.4 & 5.4 to 9.0 \\
1500 to 1999 & 13 & 3.2 & 14.2 & 2.9 & 9.7 & 8.7 & 8.0 \\
& & 2.4 to 4.0 & 10.2 to 18.2 & 2.1 to 3.7 & 6.1 to 11.3 & 6.3 to 11.1 & 5.2 to 10.8 \\
2000 to 2499 & 3 & 3.4 & 15.1 & 2.7 & 11.5 & 9.5 & 8.4 \\
\hline
\end{tabular}

Values are mean and $\pm 2 S D$.

$\mathrm{AO}$, aortic root; IVS, interventricular septum; LA, left atrium; LIDDd (s), left interventricular diameter at end diastole (end systole); LVPWd, left ventricular posterior wall thickness at end diastole.

Table 6 Cardiac dimensions ( $\mathrm{mm}$ ) at 28 days of age by gestation

\begin{tabular}{llllllll}
\hline $\begin{array}{l}\text { Gestation } \\
\text { (weeks) }\end{array}$ & $n$ & IVS & LIDDd & LVPW & LIDDs & LA & AO \\
\hline 25 to 28 & 13 & 3.3 & 13.2 & 2.9 & 9.3 & 8.1 & 7.4 \\
& & 1.8 to 4.8 & 7.5 to 19.0 & 1.8 to 4.0 & 5.8 to 12.9 & 4.1 to 12.1 & 5.4 to 9.4 \\
29 to 31 & 16 & 3.3 & 14.2 & 3.2 & 9.8 & 9.8 & 7.9 \\
& & 1.5 to 5.0 & 10.4 to 18.0 & 1.9 to 4.5 & 6.7 to 12.8 & 6.0 to 13.6 & 6.3 to 9.5 \\
32 to 33 & 4 & 3.2 & 16.4 & 3.0 & 11.1 & 10.1 & 9.0 \\
& & 2.5 to 3.9 & 14.9 to 17.9 & 2.1 to 3.9 & 8.2 to 13.9 & 7.2 to 13.0 & 8.3 to 9.7 \\
\hline
\end{tabular}

Values are mean and $\pm 2 \mathrm{SD}$.

$\mathrm{AO}$, aortic root; IVS, interventricular septum; LA, left atrium; LIDDd (s), left interventricular diameter at end diastole (end systole); LVPWd, left ventricular posterior wall thickness at end diastole.

PROCEDURES

The babies were scanned by one person (RS) with a Toshiba 140 scanner, using a $7.5 \mathrm{Mg} \mathrm{Hz}$ probe (Toshiba Medical Systems, Crawley, UK).

Each baby was examined as follows. In the supine position, the left ventricle was studied from cross sectional, parasternal long axis views on cross sectional $M$ mode echocardio- graphy. Measurements of interventricular septum, left ventricular posterior wall thickness at end diastole, and left interventricular diameter at end systole and end diastole (LIDDs, LIDDd) were taken from $M$ mode examinations at the level of the mitral valve leaflets. Aortic root and left atrial diameters were taken in diastole at the level of the aortic valves. The measurements were done by the leading edge methodology following the American Society of Echocardiography recommendations, ${ }^{4}$ as adapted by Silverman ${ }^{5}$ for premature babiesthat is, end diastole being taken as the point of maximum ventricular diameter rather than at the onset of the QRS complex, and end systole as the point of minimum ventricular diameter, as long as there is no dyskinesis of the ventricle. The pulmonary artery was then visualised on a short axis view.

Maximum blood flow velocities (Vmax) were measured in the centre of the artery, just distal to the pulmonary valve, by pulsed Doppler. Vmax across the mitral and tricuspid valves was measured from an apical four chamber view by pulsed wave Doppler from a point at the centre of the valves. Measurements were only taken when both a and e waves could be seen clearly and from waves with clean laminar flow. Vmax in the ascending and descending aorta was measured from the suprasternal position with continuous wave Doppler using a $2.5 \mathrm{MHz}$ pencil probe. The presence of a patent arterial duct was determined from a combination of direct imaging of the duct, colour flow mapping, and pulsed and continuous wave Doppler. The examinations were recorded on video and measurements averaged over three to five cardiac cycles.

The infants were examined within the first three days of life (day 0) and at seven and 28 days. The following clinical variables were noted: antenatal steroids, birth weight, gestational age (by early ultrasound in all cases), centiles, and requirements for inotropes, ventilation, and oxygen.

\section{DATA ANALYSIS}

Reference ranges of measurements and Vmax (means and standard deviations) were calculated for three week gestational age and $500 \mathrm{~g}$ birth weight bands. For infants in whom measurements were available on days 0,7 , and 28 , paired Student's $t$ tests were carried out for changes over this time. Measurements of interventricular septum, left ventricular posterior wall, LIDD, aortic root, and left atrium and all Vmax values were plotted against gestation and birth weight. Spearman rank correlations were carried out. The measurements and Vmax values were then compared, with unpaired Student's $t$ tests, for infants with patent arterial ducts and inotropic support. Interventricular septum and left ventricular posterior wall measurements were compared between infants who received antenatal dexamethasone and those who did not. A probability ( $p$ ) value of less than 0.05 was taken as significant.

The interventricular septum to left ventricular posterior wall ratio was calculated for 
Table 7 Cardiac dimensions ( $\mathrm{mm}$ ) at 28 days of age in relation to birth weight

\begin{tabular}{|c|c|c|c|c|c|c|c|}
\hline $\begin{array}{l}\text { Birth weight } \\
(g)\end{array}$ & $n$ & IVS & $L I D D d$ & $L V P W$ & LIDDs & $L A$ & $A O$ \\
\hline 500 to $1000^{\star}$ & 8 & $\begin{array}{l}3.4 \\
1.7 \text { to } 5.1\end{array}$ & $\begin{array}{l}12.1 \\
6.5 \text { to } 17.8\end{array}$ & $\begin{array}{l}3.0 \\
1.9 \text { to } 4.0\end{array}$ & $\begin{array}{l}8.6 \\
6.4 \text { to } 10.8\end{array}$ & $\begin{array}{l}7.6 \\
4.8 \text { to } 10.4\end{array}$ & $\begin{array}{l}7.3 \\
5.5 \text { to } 9.1\end{array}$ \\
\hline 1000 to 1499 & 21 & $\begin{array}{l}3.2 \\
1.7 \text { to } 4.8\end{array}$ & $\begin{array}{l}14.5 \\
10.5 \text { to } 18.5\end{array}$ & $\begin{array}{l}3.1 \\
1.9 \text { to } 4.4\end{array}$ & $\begin{array}{l}9.9 \\
6.5 \text { to } 13.2\end{array}$ & $\begin{array}{l}9.4 \\
5.6 \text { to } 13.2\end{array}$ & $\begin{array}{l}7.9 \\
6.0 \text { to } 9.8\end{array}$ \\
\hline 1500 to 2200 & 4 & $\begin{array}{l}3.3 \\
2.4 \text { to } 4.1\end{array}$ & $\begin{array}{l}16.0 \\
13.7 \text { to } 18.2\end{array}$ & $\begin{array}{l}2.8 \\
1.6 \text { to } 4.0\end{array}$ & $\begin{array}{l}11.1 \\
8.8 \text { to } 13.3\end{array}$ & $\begin{array}{l}11.3 \\
6.9 \text { to } 15.8\end{array}$ & $\begin{array}{l}8.5 \\
7.5 \text { to } 9.4\end{array}$ \\
\hline
\end{tabular}

Values are mean and $\pm 2 \mathrm{SD}$

*Includes one baby with chronic lung disease with IVS of $4.5 \mathrm{~mm}$.

AO, aortic root; IVS, interventricular septum; LA, left atrium; LIDDd (s), left interventricular diameter at end diastole (end systole); LVPWd, left ventricular posterior wall thickness at end diastole.

Table 8 Doppler maximum velocities $(\mathrm{m} / \mathrm{s})$ on days $0-3$ by gestation

\begin{tabular}{|c|c|c|c|c|c|c|}
\hline $\begin{array}{l}\text { Gestation } \\
\text { (weeks) }\end{array}$ & $n$ & $\begin{array}{l}\text { Ascending } \\
\text { aorta }\end{array}$ & $\begin{array}{l}\text { Descending } \\
\text { aorta }\end{array}$ & $\begin{array}{l}\text { Pulmonary } \\
\text { artery }\end{array}$ & Mitral valve & $\begin{array}{l}\text { Triscuspid } \\
\text { valve }\end{array}$ \\
\hline 23 to 25 & 8 & $\begin{array}{l}0.96 \\
0.74 \text { to } 1.18\end{array}$ & $\begin{array}{l}0.75 \\
0.57 \text { to } 0.93\end{array}$ & $\begin{array}{l}0.49 \\
0.35 \text { to } 0.63\end{array}$ & $\begin{array}{l}0.39 \\
0.25 \text { to } 0.53\end{array}$ & $\begin{array}{l}0.38 \\
0.16 \text { to } 0.60\end{array}$ \\
\hline 26 to 28 & 22 & $\begin{array}{l}1.07 \\
0.66 \text { to } 1.48\end{array}$ & $\begin{array}{l}0.87 \\
0.41 \text { to } 1.33\end{array}$ & $\begin{array}{l}0.58 \\
0.28 \text { to } 0.88\end{array}$ & $\begin{array}{l}0.39 \\
0.17 \text { to } 0.61\end{array}$ & $\begin{array}{l}0.43 \\
0.25 \text { to } 0.61\end{array}$ \\
\hline 29 to 31 & 17 & $\begin{array}{l}1.09 \\
0.51 \text { to } 1.67\end{array}$ & $\begin{array}{l}0.84 \\
0.48 \text { to } 1.20\end{array}$ & $\begin{array}{l}0.55 \\
0.26 \text { to } 0.84\end{array}$ & $\begin{array}{l}0.41 \\
0.18 \text { to } 0.64\end{array}$ & $\begin{array}{l}0.39 \\
0.21 \text { to } 0.57\end{array}$ \\
\hline 32 to 33 & 17 & $\begin{array}{l}1.13 \\
0.55 \text { to } 1.71\end{array}$ & $\begin{array}{l}0.89 \\
0.47 \text { to } 1.31\end{array}$ & $\begin{array}{l}0.59 \\
0.25 \text { to } 0.93\end{array}$ & $\begin{array}{l}0.46 \\
0.20 \text { to } 0.72\end{array}$ & $\begin{array}{l}0.43 \\
0.25 \text { to } 0.61\end{array}$ \\
\hline
\end{tabular}

Values are mean and $\pm 2 \mathrm{SD}$.

Table 9 Doppler maximum velocities $(\mathrm{m} / \mathrm{s})$ on days $0-3$ in relation to birth weight

\begin{tabular}{|c|c|c|c|c|c|c|}
\hline Birth weight $(g)$ & $n$ & $\begin{array}{l}\text { Ascending } \\
\text { aorta }\end{array}$ & $\begin{array}{l}\text { Descending } \\
\text { aorta }\end{array}$ & $\begin{array}{l}\text { Pulmonary } \\
\text { artery }\end{array}$ & Mitral valve & $\begin{array}{l}\text { Triscuspid } \\
\text { valve }\end{array}$ \\
\hline 500 to 1000 & 20 & $\begin{array}{l}1.01 \\
0.64 \text { to } 1.38\end{array}$ & $\begin{array}{l}0.80 \\
0.41 \text { to } 1.19\end{array}$ & $\begin{array}{l}0.58 \\
0.25 \text { to } 0.81\end{array}$ & $\begin{array}{l}0.36 \\
0.16 \text { to } 0.56\end{array}$ & $\begin{array}{l}0.40 \\
0.22 \text { to } 0.58\end{array}$ \\
\hline 1000 to 1499 & 27 & $\begin{array}{l}1.06 \\
0.57 \text { to } 1.55\end{array}$ & $\begin{array}{l}0.85 \\
0.42 \text { to } 1.28\end{array}$ & $\begin{array}{l}0.57 \\
0.31 \text { to } 0.83\end{array}$ & $\begin{array}{l}0.44 \\
0.22 \text { to } 0.66\end{array}$ & $\begin{array}{l}0.42 \\
0.24 \text { to } 0.60\end{array}$ \\
\hline 1500 to 1999 & 12 & $\begin{array}{l}1.21 \\
0.64 \text { to } 1.78\end{array}$ & $\begin{array}{l}0.93 \\
0.61 \text { to } 1.25\end{array}$ & $\begin{array}{l}0.62 \\
0.24 \text { to } 1.00\end{array}$ & $\begin{array}{l}0.44 \\
0.23 \text { to } 0.65\end{array}$ & $\begin{array}{l}0.44 \\
0.22 \text { to } 0.66\end{array}$ \\
\hline 2000 to 2499 & 2 & 1.20 & 0.80 & 0.55 & 0.46 & 0.41 \\
\hline
\end{tabular}

Values are mean and $\pm 2 \mathrm{SD}$.

Table 10 Doppler maximum velocities $(\mathrm{m} / \mathrm{s})$ on day 7 by gestation

\begin{tabular}{|c|c|c|c|c|c|c|}
\hline $\begin{array}{l}\text { Gestation } \\
\text { (weeks) }\end{array}$ & $n$ & $\begin{array}{l}\text { Ascending } \\
\text { aorta }\end{array}$ & $\begin{array}{l}\text { Descending } \\
\text { aorta }\end{array}$ & $\begin{array}{l}\text { Pulmonary } \\
\text { artery }\end{array}$ & Mitral valve & $\begin{array}{l}\text { Tricuspid } \\
\text { valve }\end{array}$ \\
\hline 23 to 25 & 6 & $\begin{array}{l}1.14 \\
0.71 \text { to } 1.57\end{array}$ & $\begin{array}{l}0.84 \\
(\mathrm{n}=1)\end{array}$ & $\begin{array}{l}0.77 \\
0.52 \text { to } 1.03\end{array}$ & $\begin{array}{l}0.52 \\
0.31 \text { to } 0.73\end{array}$ & $\begin{array}{l}0.43 \\
0.31 \text { to } 0.55\end{array}$ \\
\hline 26 to 28 & 12 & $\begin{array}{l}1.10 \\
0.78 \text { to } 1.42\end{array}$ & $\begin{array}{l}1.17 \\
0.94 \text { to } 1.40\end{array}$ & $\begin{array}{l}0.68 \\
0.42 \text { to } 0.92\end{array}$ & $\begin{array}{l}0.43 \\
0.29 \text { to } 0.57\end{array}$ & $\begin{array}{l}0.43 \\
0.23 \text { to } 0.63\end{array}$ \\
\hline 29 to 31 & 10 & $\begin{array}{l}1.25 \\
0.88 \text { to } 1.61\end{array}$ & $\begin{array}{l}0.94 \\
0.80 \text { to } 1.08\end{array}$ & $\begin{array}{l}0.68 \\
0.46 \text { to } 0.90\end{array}$ & $\begin{array}{l}0.43 \\
0.25 \text { to } 0.61\end{array}$ & $\begin{array}{l}0.48 \\
0.34 \text { to } 062\end{array}$ \\
\hline 32 to 33 & 9 & $\begin{array}{l}1.21 \\
0.67 \text { to } 1.75\end{array}$ & $\begin{array}{l}1.00 \\
0.50 \text { to } 1.5\end{array}$ & $\begin{array}{l}0.75 \\
0.47 \text { to } 1.03\end{array}$ & $\begin{array}{l}0.44 \\
0.24 \text { to } 0.64\end{array}$ & $\begin{array}{l}0.49 \\
0.37 \text { to } 0.61\end{array}$ \\
\hline
\end{tabular}

Values are mean and $\pm 2 \mathrm{SD}$. initial scan and 18 scans were remeasured. This produced good coefficients of repeatability of 0.4 to $0.5 \mathrm{~mm}$ for measurements of interventricular septum to left ventricular posterior wall, and 0.9 to $1 \mathrm{~mm}$ for measurements of LIDD.

\section{Results}

We studied 101 babies of less than 34 weeks' gestation. Six had congenital heart disease and 16 were under the 10 th centile, leaving 79 normal babies. Their initial scan was done at a mean of 25 hours, range 1 to 75 hours of age. Their characteristics are shown in table 1. Reference ranges, with means and standard deviations, for interventricular septum, LIDDd, LIDDs, left ventricular posterior wall, left atrium, and aortic root are shown in tables 2-7 and for maximum blood flow velocities in the pulmonary artery, ascending aorta, descending aorta, mitral valve, and tricuspid valve in tables 8-13. In 56 babies repeat measurements were taken on day 7 of life and 33 on day 28. Thirteen infants died and five received dexamethasone before day 28. The remaining infants were transferred back to the referring hospitals or discharged home before day 28 .

Measurements of all cardiac dimensions on day 0 showed a correlation with gestation and birth weight $(r=0.5, \mathrm{p}<0.0001)$. Interventricular septum measurements are shown in figs 1 and 2 . The Vmax values did not show any correlation. There was no difference between the dimensions or Vmax values of the infants receiving inotropic agents or those who had a patent arterial duct and those who did not. There was no difference in interventricular septum or left ventricular posterior wall dimensions of babies who received antenatal dexamethasone compared with those who did not.

Between days 0 and 7 a small increase occurred in all dimensions (table 14) which was significant for the interventricular septum and left ventricular posterior wall. Only the Vmax across the pulmonary artery increased significantly. Over the first month of life, there was a significant increase in the interventricular septum, left ventricular posterior wall, and left atrium measurements, and in Vmax across most valves.

In the first three days of life the ratio of interventricular septum to left ventricular posterior wall thickness was greater than 1.3 in $12 \%$ of babies, suggesting asymmetrical septal hypertrophy. On days 7 and 28 the proportion of babies with ratios over 1.3 was $16 \%$ and $14 \%$, respectively. There was no significant difference in gestation or birth weight in those with a ratio greater than 1.3.

The ratio of the a wave to the e wave in the mitral and tricuspid valve Doppler waves was inverted in the majority of babies. The a wave was greater than the e wave in $62-69 \%$ of mitral valve and $89-100 \%$ of tricuspid valve waves (days 0-28).

Six babies had congenital heart disease. Two had small muscular ventricular septal defects and one had mild peripheral pulmonary 
Table 11 Doppler maximum velocities $(\mathrm{m} / \mathrm{s})$ on day 7 in relation to birth weight

\begin{tabular}{|c|c|c|c|c|c|c|}
\hline Birth weight $(g)$ & $n$ & $\begin{array}{l}\text { Ascending } \\
\text { aorta }\end{array}$ & $\begin{array}{l}\text { Descending } \\
\text { aorta }\end{array}$ & $\begin{array}{l}\text { Pulmonary } \\
\text { artery }\end{array}$ & Mitral valve & $\begin{array}{l}\text { Tricuspid } \\
\text { valve }\end{array}$ \\
\hline 500 to 1000 & 17 & $\begin{array}{l}1.17 \\
0.73 \text { to } 1.61\end{array}$ & $\begin{array}{l}1.02 \\
0.52 \text { to } 1.52\end{array}$ & $\begin{array}{l}0.71 \\
0.43 \text { to } 0.99\end{array}$ & $\begin{array}{l}0.46 \\
0.26 \text { to } 0.66\end{array}$ & $\begin{array}{l}0.44 \\
0.28 \text { to } 0.60\end{array}$ \\
\hline 1000 to 1499 & 14 & $\begin{array}{l}1.15 \\
0.77 \text { to } 1.52\end{array}$ & $\begin{array}{l}0.98 \\
0.56 \text { to } 1.30\end{array}$ & $\begin{array}{l}0.70 \\
0.50 \text { to } 0.90\end{array}$ & $\begin{array}{l}0.42 \\
0.26 \text { to } 0.58\end{array}$ & $\begin{array}{l}0.45 \\
0.29 \text { to } 0.61\end{array}$ \\
\hline 1500 to 1999 & 8 & $\begin{array}{l}1.12 \\
0.84 \text { to } 1.40\end{array}$ & $\begin{array}{l}0.94 \\
0.86 \text { to } 1.02\end{array}$ & $\begin{array}{l}0.67 \\
0.47 \text { to } 0.87\end{array}$ & $\begin{array}{l}0.45 \\
0.27 \text { to } 0.62\end{array}$ & $\begin{array}{l}0.46 \\
0.36 \text { to } 0.56\end{array}$ \\
\hline
\end{tabular}

Values are mean and $\pm 2 S D$.

Table 12 Doppler maximum velocities ( $\mathrm{m} / \mathrm{s}$ ) on day 28 by gestation

\begin{tabular}{|c|c|c|c|c|c|c|}
\hline $\begin{array}{l}\text { Gestation } \\
\text { (weeks) }\end{array}$ & $n$ & $\begin{array}{l}\text { Ascending } \\
\text { aorta }\end{array}$ & $\begin{array}{l}\text { Descending } \\
\text { aorta }\end{array}$ & $\begin{array}{l}\text { Pulmonary } \\
\text { artery }\end{array}$ & Mitral valve & $\begin{array}{l}\text { Tricuspid } \\
\text { valve }\end{array}$ \\
\hline 25 to 28 & 12 & $\begin{array}{l}1.09 \\
1.03 \text { to } 1.16\end{array}$ & $\begin{array}{l}1.26 \\
0.79 \text { to } 1.73\end{array}$ & $\begin{array}{l}0.78 \\
0.57 \text { to } 1.00\end{array}$ & $\begin{array}{l}0.57 \\
0.36 \text { to } 0.79\end{array}$ & $\begin{array}{l}0.60 \\
0.34 \text { to } 0.86\end{array}$ \\
\hline 29 to 31 & 14 & $\begin{array}{l}1.03 \\
0.67 \text { to } 1.40\end{array}$ & $\begin{array}{l}1.35 \\
0.83 \text { to } 1.87\end{array}$ & $\begin{array}{l}0.84 \\
0.60 \text { to } 1.09\end{array}$ & $\begin{array}{l}0.64 \\
0.36 \text { to } 0.92\end{array}$ & $\begin{array}{l}0.59 \\
0.27 \text { to } 0.91\end{array}$ \\
\hline 32 to 33 & 4 & $\begin{array}{l}1.49 \\
0.69 \text { to } 2.29\end{array}$ & $\begin{array}{l}- \\
-\end{array}$ & $\begin{array}{l}0.79 \\
0.53 \text { to } 1.04\end{array}$ & $\begin{array}{l}0.73 \\
0.38 \text { to } 1.08\end{array}$ & $\begin{array}{l}0.63 \\
0.39 \text { to } 0.88\end{array}$ \\
\hline
\end{tabular}

Values are mean and $\pm 2 S D$.

Table 13 Doppler maximum velocities $(\mathrm{m} / \mathrm{s})$ on day 28 in relation to birth weight

\begin{tabular}{|c|c|c|c|c|c|c|}
\hline Birth weight (g) & $n$ & $\begin{array}{l}\text { Ascending } \\
\text { aorta }\end{array}$ & $\begin{array}{l}\text { Descending } \\
\text { aorta }\end{array}$ & $\begin{array}{l}\text { Pulmonary } \\
\text { artery }\end{array}$ & Mitral valve & $\begin{array}{l}\text { Tricuspid } \\
\text { valve }\end{array}$ \\
\hline 500 to 1000 & 7 & $\begin{array}{l}1.07 \\
0.79 \text { to } 1.37\end{array}$ & $\begin{array}{l}1.28 \\
0.55 \text { to } 2.02\end{array}$ & $\begin{array}{l}0.76 \\
0.54 \text { to } 0.99\end{array}$ & $\begin{array}{l}0.54 \\
0.24 \text { to } 0.84\end{array}$ & $\begin{array}{l}0.56 \\
0.14 \text { to } 0.98\end{array}$ \\
\hline 1000 to 1499 & 19 & $\begin{array}{l}1.04 \\
0.53 \text { to } 1.56\end{array}$ & $\begin{array}{l}1.36 \\
0.90 \text { to } 1.81\end{array}$ & $\begin{array}{l}0.84 \\
0.61 \text { to } 1.06\end{array}$ & $\begin{array}{l}0.66 \\
0.42 \text { to } 0.90\end{array}$ & $\begin{array}{l}0.61 \\
0.39 \text { to } 0.84\end{array}$ \\
\hline
\end{tabular}

Values are mean and $\pm 2 \mathrm{SD}$.

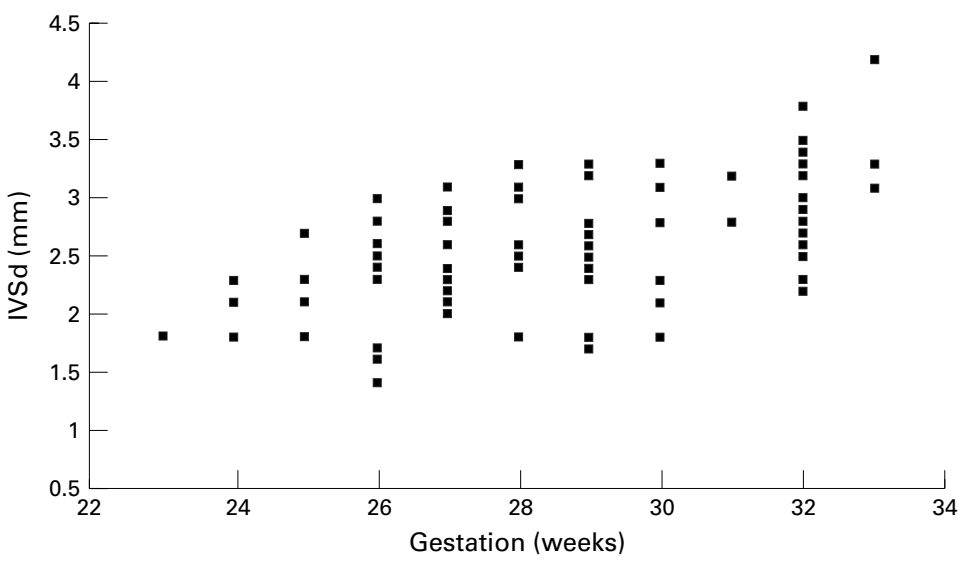

Figure 1 Correlation of measurements of interventricular septum in diastole with gestation in normal preterm infants within three days of birth.

stenosis. These infants did not become symptomatic, but all developed a systolic murmur, and a patent arterial duct was initially suspected. Three babies died with the following conditions: interrupted aortic arch with biliary atresia, hypoplastic left heart, and cardiomyopathy thought to be secondary to severe twin to twin transfusion. The overall incidence of congenital heart disease in our preterm population was $6 \%$-a very high incidence, almost 10 times that of the term population. While this is a point of interest, it should not be overinterpreted as it includes many transferred babies in a highly selected population.

\section{Discussion}

We present reference ranges of cardiac dimensions and maximum blood flow velocities for a complete population of preterm infants. There is a close correlation with both gestation and birth weight for all measurements (figs 1 and 2). Either can be used for reference ranges. Doppler measurements of maximum blood flow velocity, however, appear to be more independent of gestation and birth weight.

A small increase in most measurements was seen over time. This has been well shown in term and older infants, ${ }^{7}$ but not previously documented in preterm babies over such a small age range. Reference ranges and research needs to take these changes into account, and further work on this change of measurements is needed.

Reference ranges do exist for preterm babies, but are less helpful for modern neonatal units. Studies available include small numbers of very preterm infants and usually include measurements done over a wide age range. In 1973 Solinger et al published a series of measurements which included preterm infants, all over $2750 \mathrm{~g}$ in weight. ${ }^{1}$ In 1978 Lange et al reported a series of 91 more premature infants, ${ }^{2} 49$ of whom were less than $2500 \mathrm{~g}$ in weight. Both studies included infants up to 3 weeks of age. Lange et al in $1983^{\circ}$ and Walthner et al in $1986^{\circ}$ produced new ranges of left heart and interventricular septum measurements. Between them they examined over 300 babies, but only between one and two thirds were preterm, and again very few were extremely preterm. Walther's infants were studied between birth and 5 days of age. In these studies values were given in terms of birth weight but not gestation. Correlation of the measurements with gestation has not previously been done.

Left atrium and aortic root have been measured more often than the remainder of the heart: two large series in the 1980 s examined a total of 282 babies, ${ }^{11}{ }^{11}$ with a much larger proportion down to 28 weeks' gestation. The values reported in these studies are closely comparable with our measurements of the same birth weight groups.

Previously published studies are all over 10 years old. The quality of scanning has improved considerably over this time. ${ }^{12} \mathrm{M}$ mode scanning has progressed from stand alone $M$ mode to cross sectional scanning, allowing better and easier positioning of the $M$ mode for more accurate measurement. Doppler measurements of blood flow velocity, and the small pencil probes, which make this technique possible in the tiny preterm infant, are even more recent advances. We are not aware of any published data on normal Doppler velocities in preterm babies, although reference ranges for cardiac output in preterm infants have been published. ${ }^{13}$

The numbers of infants at 28 days are quite small and may not provide such a useful reference range as those at 0 and 7 days. In practice, however, most scans are done within the first week of life. It is these ranges which we hope will be most useful. The measurement of dimensions at 28 days were mainly done to see 


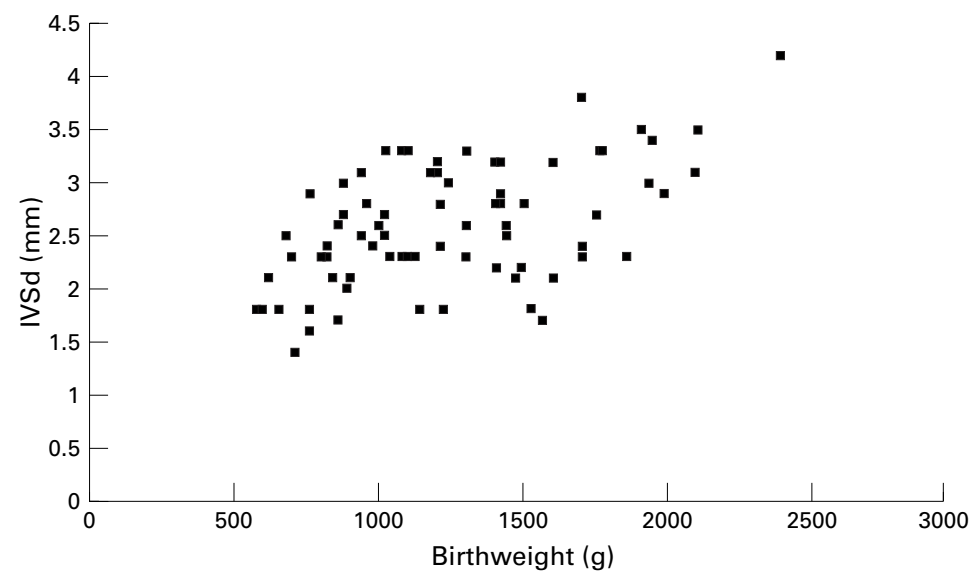

Figure 2 Correlation of measurements of interventricular septum in diastole with birth weight in normal preterm infants within three days of birth.

Table 14 Increase in cardiac measurements and Doppler maximum velocities over time (\% of baseline)

\begin{tabular}{llllllll}
\hline $\begin{array}{l}\text { Cardiac } \\
\text { measurements }\end{array}$ & $n$ & IVS & LVPW & LIDDd & LIDDs & LA & AO \\
\hline Day 0-7 & 55 & $14(50) \%^{\star \star \star} 16(56) \%^{\star \star \star}$ & $2(16) \%$ & $-1(19) \%$ & $9(60) \%$ & $4(27) \%$ \\
Day 0-28 & 28 & $16(51) \% \star \star \star$ & $24(58) \% \star \star \star$ & $13(36) \%$ & $6(50) \%$ & $36(65) \% \star \star \star$ & $11(43) \% \star$ \\
& & & & & \\
Maximum & & Descending & Ascending & Pulmonary & Mitral & Tricuspid & \\
velocities & & aorta & aorta & artery & valve & valve & \\
Day 0-7 & & $12(50) \%$ & $6(42) \%$ & $35(90) \%$ & $13(60) \%$ & $8(48) \%$ & \\
Day 0-28 & & $32(76) \% \star \star \star 27(60) \% \star$ & $51(77) \% \star \star \star$ & $70(84) \% \star \star \star$ & $39(68) \%$ & \\
\hline
\end{tabular}

Values are mean (SD).

Paired Student's $t$ test: ${ }^{\star} \mathrm{p}<0.05 ;{ }^{\star \star \star} \mathrm{p}<0.001$.

$\mathrm{AO}$, aortic root; IVS, interventricular septum; LA, left atrium; LIDDd (s), left interventricular diameter at end diastole (systole); LVPW, left ventricular posterior wall thickness.

whether there was a significant change over this short period.

It was noteworthy that having a patent arterial duct or being on inotropic drugs did not affect the cardiac dimensions. Of particular interest was the fact that the left atrium was not enlarged in infants with a patent arterial duct, compared with those without, on days 0 and 7 . This rather surprising finding probably reflects the timing of measurements. In the first few days of life in preterm infants the arterial duct is often open, but the effect of this is probably not significant, so an enlarged left atrium is not always seen in the early stages. By day 28 the mean left atrium to aortic root ratio was greater, but it is likely that the numbers were too small to show a significant difference.

There were some interesting differences between our preterm population and adult and paediatric populations. The increased interventricular septum to left ventricular posterior wall ratio in $12 \%$ of "normal" preterm infants within the first three days of life suggests that mild asymmetrical septal hypertrophy is a normal finding in this population. Obviously these are not completely normal preterm infants, as they are not experiencing the normal intrauter- ine life. An important finding was that antenatal dexamethasone does not appear to affect the thickness of the left ventricular wall (interventricular septum or left ventricular posterior wall). This is in contrast to dexamethasone given in postnatal life, which causes a very marked thickening. ${ }^{3}$

The ratio of the sizes of the e and a waves is inverted in the preterm population, even up to day 28 . The e wave, produced by passive filling of the ventricle, was smaller than the a wave, caused by atrial systole. In older patients this is usually the result of left ventricular diastolic dysfunction secondary to conditions which cause cardiac hypertrophy. Like the interventricular septum to left ventricular posterior wall ratio, the waveforms for mitral and tricuspid flow suggest that even well, healthy preterm babies have hearts which are either mildly dysfunctional or function differently from those of older infants.

Echocardiograms in preterm babies clearly differ from that seen in older children and adults. It is important to know which features are normal or abnormal in this population. Further work in this respect is required. In the meantime we present reference ranges for cardiac measurements and Doppler velocities, using current modern scanning equipment for a preterm population over a 28 day period.

1 Solinger R, Elbl F, Minhas K. Echocardiography in the normal neonate. Circulation 1973;47:108-17.

2 Lange L, Fabecic-Sabadi V, Bein G. Echokardiographische Normalwerte bei Fruh und neugeborenen. Z Kardiol 1978;

3 Evans N. Cardiovascular effects of dexamethasone in the preterm infant. Arch Dis Child 1994;70:F25-30.

4 Henry WL, De Maria A, Gramiak R, et al. Report of the American Society of Echocardiography Committee on nomenclature and standards in 2 dimensional echocardiography. Circulation 1980;62:212-17.

5 Silverman N. Quantitative methods to enhance morphological information using M-mode Doppler and cross sectional ultrasound. In: Silverman N, ed. Paediatric echocardiography. London: Williams and Wilkins, 1993:35-6.

6 Bland JM, Altman DG. Statistical methods for assessing agreement between two methods of clinical measurement. Lancet 1986;i:307-10.

7 Oberhansli I, Brandon G, Lacourt G, et al. Growth patterns of cardiac structures and changes in systolic time intervals in the newborn and infant. Acta Paediatr Scand 1980;69: in the new $239-47$.

8 Lange L, Fabecic-Sabadi V, Bein G. Comparative overview of normal echocardiographic values for children ranging from premature newborn to the adolescent. Herz 1983;8: $105-21$

9 Walther F, Siassi B, King J, et al. Echocardiographic measurements in normal preterm and term neonates. Acta Paediatr Scand 1986;75:563-8.

10 Walther FJ, Siassi B, King J, et al. Normal values of aortic root measurements in neonates. Pediatr Cardiol 1985; 6:614.

11 Reller MD, Meyer RA, Kaplan, S. Normal aortic root measurements in premature infants. F Clin Ultrasound 1983;11: 203-5.

12 Rice MJ, McDonald RW, Reller MD, et al. Pediatric echocardiography: current role and a review of technical echocardiography: current role and

13 Walther FJ, Siassi B, Ramadan NA, et al. Pulsed Doppler determinations of cardiac output in neonates: normal standards for clinical use. Pediatrics 1985;76:829-33. 